\title{
Kearifan Lokal Petani Tradisional Samin di Desa Klopoduwur, Kecamatan Banjarejo, Kabupaten Blora
}

\section{Local Wisdom of Traditional Samin Farmers in Klopoduwur Village, Banjerejo Sub-District, Blora District}

\author{
Dwiyana Anela Kurniasari $^{1 *}$, Edi Dwi Cahyono ${ }^{2}$, Yayuk Yuliati² \\ I*Program Studi Sosiologi, Pascasarjana Fakultas Pertanian, Universitas Brawijaya, Jl. Veteran, \\ Malang 65145, Indonesia \\ ${ }^{2}$ Jurusan Sosial Ekonomi, Fakultas Pertanian, Universitas Brawijaya, Jl. Veteran, Malang 65145, \\ Indonesia
}

Received: 20 December 2017; Revised: 31 August 2018; Accepted: 4 September 2018

\begin{abstract}
ABSTRAK
Masyarakat adat di Indonesia sebagian besar tinggal di daerah pedesaan, sehingga pekerjaan utama mereka adalah petani. Masyarakat adat melakukan usahatani secara tradisional sesuai dengan ketentuan adat dan menggunakan teknologi sederhana dalam usahatani sehingga mereka dapat disebut petani tradisional. Salah satu masyarakat adat di Indonesia yang masih melakukan usaha tani dengan cara tradisional adalah Masyarakat Adat Samin. Lokasi petani tradisional Samin berada di Desa Klopoduwur Kecamatan Banjarejo Kabupaten Blora. Petani tradisional Samin dalam melakukan kegiatan usahatani masih sesuai dengan adat ajaran Samin. Petani tradisional Samin masih menjalankan tata cara adat dalam bidang pertanian yang diwariskan oleh leluhurnya secara turun temurun hingga sekarang. Menjadi petani merupakan pekerjaan mulia bagi mereka, sehingga mereka melakukan upacara-upacara dan ritual adat untuk bersyukur dengan pekerjaan mereka. Kearifan lokal pertanian yang masih dijalani hingga sekarang oleh petani tradisional Samin adalah tidak menjual seluruh hasil panennya, tidak menjual lahan pertanian mereka kepada orang luar masyarakat Adat Samin, melakukan upacara adat Jamasan dan upacara persembahan syukur kepada alam yaitu Kadeso.
\end{abstract}

Kata kunci: petani tradisional; kearifan local; upacara adat

\section{ABSTRACT}

Indigenous peoples in Indonesia live mostly in rural areas, so their main job is farmers. Indigenous peoples conduct traditional farming in accordance with tradition provisions and use simple technology in farming so they can be called traditional farmers. One of the indigenous peoples in Indonesia who are still doing farming in the traditional way is the Indigenous Peoples Samin. Locations of traditional Samin farmers are located in Klopoduwur Village, Banjarejo Sub-district, Blora District. Traditional Samin farmers in conducting farming activities are still in accordance with the Samin traditions. Traditional Samin farmers still run customary procedures in the field of agriculture inherited by his ancestors from generation to generation until now. Being a farmer is a noble job for them, so they perform a traditional ceremony to be thankful with their work. The local agricultural wisdom that is still practiced today by traditional Samin farmers is not selling all their crops, not selling their farms to outsiders of Indigenous Samin, doing traditional Jamasan ceremonies and offering ceremonies of gratitude to nature ie Kadeso

Keywords: traditional farmers; local wisdom; traditional ceremonies

How to cite:

Kurniasari, D. A., Cahyono, E. D., \& Yuliati, Y. (2018). Kearifan Lokal Petani Tradisional Samin di Desa Klopoduwur, Kecamatan Banjarejo, Kabupaten Blora. Habitat, 29(1), 33-37. https://doi.org/10.21776/ub.habitat.2018.029.1.4 


\section{Pendahuluan}

Masyarakat di Indonesia sebagian besar tinggal di daerah pedesaan dan hanya sebagian kecil yang tinggal di perkotaan, ini mencirikan bahwa negara Indonesia merupakan negara agraris yaitu negara pertanian. Diketahui bahwa dalam masyarakat agraris dimana kehidupanya masih tergantung pada hasil produksi tanah sebagai sarana produksi pokok dan memiliki corak yang homogen dalam mata pencaharian yaitu sebagai petani, karena sebagian besar masyarakat yang tinggal di desa bermata pencaharian pertanian atau usaha-tani. (Yuliati dan Purnomo, 2003)

Pertanian merupakan pekerjaan utama bagi masyarakat pedesaan. Menurut Badan Pusat Statistik (2010) dalam Denura (2017), jumlah lahan yang tersedia bagi petani di Indonesia adalah sebesar 8.111.593 ha. Lahan pertanian tersebut terletak di daerah pedesaan dan hanya sebagian kecil saja yang terletak di daerah perkotaan.

Indonesia memiliki 1.340 suku yang tersebar di seluruh penjuru nusantara (BPS, 2014). Suku-suku yang masih bertahan saat ini tinggal d wilayah pedesaan. Mereka memanfaatkan lahan pertanian sebagai modal untuk menunjang kehidupan keluarga. Pertanian menjadi hal yang tidak dapat dipisahkan dari masyarakat adat di Indonesia. Ilmu usahatani yang mereka dapatkan merupakan warisan dari leluhur yang diberikan secara turun temurun serta masih menggunakan peralatan-peralatan pertanian tradisiona. Para petani ini disebut petani tradisional, dalam menjalankan usaha taninya mereka masih sesuai dengan ketentuan-ketentuan adat. Mereka meyakini bahwa antara alam dan adat istiadat mereka tidak dapat terpisahkan. Karena kegiatan pertanian sangat tergantung pada kondisi alam, sehingga mereka juga harus menghormati alam sebagai balasan dari limpahan hasil panen mereka dengan cara melaksanakan ritual-ritual adat. Menurut Dila dan Sudrajat (2017), dengan melaksanakan ritual-ritual adat dapat dipercayai masyarakat bahwa hasil panen yang didapatkan melimpah sehingga memberikan keuntungan yang cukup besar untuk memenuhi kebutuhan.

Petani tradisional memiliki pengetahuan lokal yang mereka gunakan untuk usaha tani. Mereka masih meyakini dan menjalani pengetahuan tersebut hingga saat ini. Menurut

\footnotetext{
*) Penulis Korespondensi.

E-mail: dwiyana.anela@gmail.com

Telp: +62-822-45441160
}

Langerodi (2013) petani tradisional memiliki pengetahuan lokal yang dapat dimanfaatkan sebagai prinsip untuk mengembangkan pemberdayaan pertanian. Pengetahuan lokal yang dimiliki oleh petani tradisional merupakan pengetahuan warisan leluhur sehingga merea dapat bertahan hingga saat ini.

Petani tradisional Samin di Desa Klopoduwur Kecamatan Banjerejo, Kabupaten Blora termasuk dalam petani yang masih menjalankan usahataninya sesuai dengan ketentuan-ketentuan Adat Samin. Petani tradisional Samin merupakan masyarakat Adat Samin yang masih menjalani kehidupan mereka sesuai dengan adat istiadat Samin. Petani tradisional Samin telah menjalani pertanian sesuai adat istiadat sejak Samin Surosentiko datang ke desa mereka. Walaupun sudah berjalan sejak tahun 1840, mereka masih menjalani dan melakukan usahatani sesuai dengan adat Samin.

Tujuan dari penelitian ini adalah mendeskripsikan kearifan lokal petani tradisional Samin yang masih dijalani dan diyakini hingga sekarang. Sehingga dengan tujuan ini dapat mengetahui karakteristik pengetahuan lokal petani tradisional Samin yang dapat dimanfaatkan untuk pemberdayaan pertanian di wilayah Kabupaten Blora.

\section{Metode Penelitian}

Metode penelitian yang digunakan adalah deskriptif kualitatif. Metode penentuan lokasi penelitian menggunakan metode purposive. Penentuan lokasi di Desa Klopoduwur Kecamatan Banjarejo Kabupaten Blora sebagai pusat peradaban masyarakat Adat Samin yang saat ini sedang dalam proses pembangunan Desa Wisata. Metode penentuan informan dilakukan dengan teknik snowball sampling, Teknik pengumpulan data yang akan digunakan pada penelitian ini adalah wawancara mendalam, observasi, focus group discussion.

\section{Hasil dan Pembahasan}

\subsection{Sejarah Munculnya Masyarakat Samin di Blora}

Ajaran Saminisme muncul pertama kali di Kabupaten Blora dipimpin oleh Samin Surosentiko dan menjadi awal bagi berkembannya peradaban masyarakat Samin di Kabupaten Blora. Beliau merupakan seorang keturunan asli Jawa Tengah yang lahir pada tahun 1859 di Kabupaten Blora. Samin Surosentiko memiliki nama asli 
yaitu Raden Kohar. Beliau merupakan putra dari Raden Mas Brotodiningrat atau Raden Surowodjoyo, ayahnya adalah seorang Bupati yang berkuasa pada tahun 1802-1826. Raden Surowodjoyo sejak beliau kecil mendapatkan pendidikan di wilayah keraton kerajaan dengan segala kemewahan dan fasilitasnya. Namun di dalam lubuk hatinya timbul perlawanan karena beliau mengetahui bahwa rakyatnya sengsara karena penjajahan pemerintah Belanda. Pada tahun 1840, Raden Surowidjoyo memberanikan diri untuk meninggalkan keraton dan segela kemewahannya, kemudian membentuk kelompok yang terdiri dari para pemuda diberi nama Tiyang Sami Amin. Kelompok pemuda ini seperti tokoh Robin Hood dari Amerika, dengan pimpinan Raden Surowidjoyo mereka melakukan perampokan dengan target antek-antek pemerintah Kolonial Belanda dan membagikan hasil rampokan tersebut kepada rakyar yang miskin.

Pada tahun 1859, Raden Surowidjoyo memiliki anak laki-laki yang kemudian melanjutkan perjuangan ayahnya melawan Pemerintah Kolonial Belanda. Anak dari Raden Surowidyojo memakai nama Samin Surosentiko. Samin Surosentiko datang ke Desa Klopoduwur di Kabupaten Blora dan memutuskan untuk menetap disana. Samin Surosentigo mengajarkan berbagai ajaran yang menyimpang dari kehidupan masyarakat Jawa pada umumnya. Masyarakat Samin memiliki tata cara dalam menjalani kehidupan layaknya masyarakat etnis Jawa, sehingga mereka disebut etnis tersendiri yaitu Suku Samin. Samin Surosentiko dan pengikutnya melakukan pembangkangan terhadap penjajahan pemerintah Kolonial Belanda semakin gencar disebarkan ke berbagai daerah di sekita Kabupaten Blora. Pada akhirnya, 8 November 1907 Mbah Samin ditangkap dan dibuang oleh Belanda kemudian diasingkan di Sawahlunto, Sumatera Barat. Samin Surosentiko akhirnya meninggal di pengasingannya pada tahun 1914 dan dimakamkan di Sawahlunto Sumatera Barat.

Sepeninggalnya guru masyarakat Samin yaitu Samin Surosentiko, ajaran Samin ini diteruskan oleh murid setia Samin Surosentiko yaitu Mbah Engkrek. Hingga saat ini Mbah Engkrek dikenal sebagai salah satu tokoh Samin di Desa Klopoduwur, Kecamatan Banjarejo, Kabupaten Blora. Mbah Engkrek selalu mewariskan ajaran Samin kepada keturunannya yang laki-laki untuk diamanahi sebagai penerus beliau untuk tetap mempertahankan dan menyebarkan ajaran Samin. Keturunan Mbah Engkrek yang menjadi tokoh Adat Samin saat ini adalah Mbah Lasio. Beliau tinggal di Dusun Karangpace Desa Klopoduwur Kecamatan Banjarejo Kabupaten Blora bersama dengan masyarakat Adat Samin lainnya. Sampai saat ini Mbah Lasio masih melaksanakan dan menyebarkan ajaran Samin kepada pengikut setianya.

\subsection{Mengenal Petani Tradisional Samin Klopoduwur}

Masyarakat Adat Samin di Dusun Karangpace Desa Klopoduwur mayoritas bekerja sebagai petani. Pekerjaan ini telah dilakukan sejak awal munculnya ajaran Samin. Bertani merupakan bagian dari masyarakat Adat Samin yang tidak dapat dipisahkan. Walaupun pada saat ini generasi-generasi mudanya juga mulai melakukan pekerjaan lain. Namun bertani tetap menjadi pekerjaan utama di dalam keluarga masyarakat Adat Samin.

Menurut Hariadi (2016), masyarakat Adat Samin termasuk dalam petani tradisonal atau istilah jawanya adalah petani utun. Petani Samin mengerjakan sawah yang sebagian besar merupakan warisan dari leluhur mereka, masyarakat Adat Samin dalam ajarannya tidak diperbolehkan untuk menjual lahan sawah mereka kepada orang lain. Sehingga sawah yang mereka miliki merupakan warisan turun temurun. Selain mengerjakan sawah, masyarakat Adat Samin juga termasuk dalam petani pesanggem yang dipinjami lahan oleh Perhutani untuk ditanami komoditas pertanian. Wilayah perkampungan Samin termasuk dalam wilayah KPH Blora, sehingga pihak KPH Blora yang selama ini menjadi mitra masyarakat Adat Samin

Masyarakat Samin bekerja di sawah dari mulai pukul 07.00 hingga 12.00 kemudian kembali lagi ke lading pukul 13.30 hingga 16.30. Komoditas yang ditanam oleh petani Samin adalah padi, jagung dan ketela. Mereka juga menanam sayuran dan buah-buahan seperti bayam, labu kuning, cabai, pisang, manga jambu. Tanaman-tanaman tersebu ditanam di sekitar halaman rumah mereka. Masyarakat Samin lebih menyukai memasak dengan hasil lading sendiri karena dinilai lebih sehat dan hemat.

Pertanian yang dilakukan petani tradisional Samin masih menggunakan bahan-bahan organik, karena petani tradisional Samin memahami apabila menggunakan bahan kimia terlalu banyak dapat merusak lingkungan. Ajaran Samin 
mengajarkan bahwa dalam mendapatkan kebutuhan sehari-hari tidak boleh merusak lingkungan, karena alam merupakan sumber penghidupan mereka. Sehingga untuk dapat mencukupi unsur hara tanaman, petani tradisional Samin menggunakan bahan organik seperti pupuk kandang sebagai penyubur tanah. (Widodo, 2009)

\subsection{Kearifan Lokal Masyarakat Samin}

Petani Samin termasuk dalam petani tradisional, istilah Jawa-nya adalah Petani 'utun'. Petani Samin melakukan usaha tani dengan caracara yang masih tradisional termasuk mematuhi aturan-aturan adat dalam bertani. Ajaran Samin yang mereka yakini telah mengatur hal-hal apa saja yang boleh dan tidak boleh dilakukan, serta adanya ritual-ritual yang dilakukan oleh petani Samin supaya selalu mendapatkan berkah dengan panen yang melimpah. Berikut merupakan kearifan lokal petani tradisional Samin yang masih dijalanin sampai sekarang:

\subsection{Mempertahankan Lahan Pertanian Warisan}

Petani Samin telah menetap di wilayah Dusun Karangpace Desa Klopoduwur sejak datangnya Samin Surosentiko di Kabupaten Blora. Pertanian menjadi pekerjaan utama masyarakat Samin sejak saat itu hingga sekarang. Lahan pertanian yang digunakan saat ini merupakan hasil dari warisan leluhurnya.

Dalam ajaran tata cara kehidupan masyarakat Samin, merek tidak diperbolehkan untuk menjual tanah mereka khususnya tanah untuk lahan pertanian. Menurut Mbah Lasio dalam wawancara mendalam, dalam ajaran Samin tanah bukan merupakan milik pribadi, namun milik alam semesta sehingga tidak diperbolehkan untuk dijual kepada orang lain. Selain itu dengan menjual tanah, dikhawatirkan masyarakat Samin dapat berpisah dari kelompoknya atau keluar dari perkampungan Samin. Menjaga tanah mereka tetap menjadi milik petani Samin dapat mempertahankan adat istiadat dan budaya mereka supaya tidak hilang dengan kemajuan jaman.

\subsection{Peraturan Adat Samin Tidak Menjual Seluruh Hasil Panennya}

Petani Samin menanam tanaman padi sebagai salah satu tanaman yang wajib ditanam. Selain padi ada juga yang menanam ketela dan jagung. Dalam bertani, Petani Samin juga diatur oleh Adat yaitu tidak boleh menjual seluruh hasil panennya. Setelah panen mereka akan menyimpan hasil panennya untuk digunakan konsumsi keluarga dan digunakan sebagai sumbangan jika ada masyarakat Samin lainnya sedang hajatan perkawinan atau sunatan.

Hasil panen yang diperoleh petani Samin, seperti contohnya padi tidak akan diselep secara keseluruhan namun bertahap sesuai dengan kebutuhan. Hasil panen yang dijual hanya sebagian saja untuk digunakan memenuhi kebutuhan sehari-hari. pada jaman dahulu masyarakat Adat Samin tidak diperbolehkan untuk menjual hasil panennya. Karena pada ajaran Samin terdapat anjuran yang berbunyi "Sak apikapike adol, luwih apik yen tuku" artinya sebaikbaiknya menjual lebih baik membeli. Namun masyarakat Samin pada jaman sekarang telah menyesuaikan perkembangan jaman dengan menjual sebagian hasil panennya dan menyimpan sisanya untuk dikonsumsi sendiri. Uang hasil penjualan panennya biasanya digunakan untuk membeli kebutuhan sandang, pangan, papan lainnya. Masyarakat Samin biasanya akan menjual hasil panen mereka kepada pengepul yang berada di perkampungan mereka. Pengepul yang juga merupakan masyarakat Adat Samin akan menjual ke Pasar Blora.

\subsection{Upacara Adat Pensucian Alat-alat Pertanian: Jamasan}

Petani Samin sangat menghargai pekerjaannya sebagai petani, menurut mereka menjadi petani adalah pekerjaan yang mulia karena tidak menggangu milik pemerintah dan tidak merusak alam secara berlebihan.

Petani Samin menghargai pekerjaannya sebagai petani diwujudkan dengan adanya upacara pensucian alat-alat pertanian yang disebut sebagai upacara adat Jamasan. Jamasan merupakan suatu upacara adat untuk mensucikan barang-barang yang dianggap sakral, bagi masyarakat Adat Samin peralatan pertanian merupakan benda yang sakral bagi mereka. Karena benda-benda tersebut yang membantu mereka untuk memenuhi kebutuhan hidup sehingga mereka dapat menjalankan ajaran Samin dengan baik. Alat-alat pertanian yang disucikan dalam upacara adat Jamasan antara lain sabit dan cangkul.

\subsection{Upacara Persembahan Syukur Kepada Alam: Kadeso}

Petani Samin sangat percaya bahwa yang memberikan kesuburan dan limpahan hasil panen adalah alam semesta. Sehingga mereka tidak akan 
merusak alam untuk mendapatkan kuntungan dari kegiatan pertaniaannya.

Salah satu cara petani Samin berucap syukur kepada alam, mereka melakukan upacara adat Kadeso. Pada upacara Adat Kadeso, masingmasing petani Samin akan membuat tumpeng untuk berdoa bersama di sumber air dekat lahan pertanian mereka. Upacara Kadeso ini dipimpin oleh Mbah Lasio, doa dilakukan di dekat sumber air karena mereka berharap alam akan selalu memberikan, air yang berlimpah, sehingga mereka tidak akan mengalami kekeringan pada tahun mendatang.

Upacara adat Kadeso dilakukan satu tahun sekali pada bulan Juli sesuai dengan perhitungan tanggalan Jawa yang ditentukan oleh Mbah Lasio. Seluruh petani Samin wajib mengikuti upacara tersebut, karena upacara ini adalah kesempatan mereka untuk mengucap rasa syukur kepada alam.

Menurut Retnaningsih (2010), masyarakat yang berpegang pada adat cenderung melaksanakan ritual-ritual sebagai bentuk nilainilai tradisional yang masih dijaga bersama. Terjaganya nilai-nilai tradisonal tersebut memberikan dampak positif dengan masih adanya kebersamaan dan kepatuhan terhadap adat.

\section{Kesimpulan}

Petani Samin merupakan petani tradisional yang masih melakukan kegiatan pertanian sesuai dengan adat istiadat ajaran Samin. Pekerjaan sebagai petani merupakan pekerjaan yang mulia bagi mereka karena tidak mengganggu orang lain dan tidk merusak alam secara berlebihan. Kearifan lokal petani Samin adalah mempertahankan lahan pertanian hasil warisan dengan tidak menjualnya kepada orang lain. Dengan aturan ini diharapkan masyarakat Samin akan tetap bertahan di perkampungan mereka dan menjaga adat istiadat agar tidak hilang. Petani Samin juga tidak menjual seluruh hasil panennya, karena mereka akan menyimpannya sebagai konsumsi keluarga serta digunakan untuk memberikan sumbangan kepada keluarga yang punya hajat. Petani Samin melakukan upacara adat Jamasan untuk mensucikan alat-alat pertaniannya dan upacara adat Kadeso untuk megucap syukur kepada alam. Mereka percaya bahwa dengan mensucikan alat yang digunakan untuk bekerja dapat membawa keberkahan bagi mereka.

\section{Daftar Pustaka}

Badan Pusat Statistik, 2014. Statistik Lahan Pertanian. Jakarta: Kementerian Pertanian.

Dila, Ria Fara dan Arif Sudrajat. 2017. Ritual Keleman Dan Metik Bagi Petani Desa Wonokasian, Kecamatan Wonoayu, Kabupaten Sidoarjo. Paradigm, 5(3), 1-9.

Denura, Farida. 2017. Di Indonesia Ada 1.340 Suku Bangsa dan 300 Kelompok Etnik. Diambil dari http:// www. netralnews.com/news/rsn/read/71459/di.in donesia.ada.1340.suku.bangsa.dan.300.kel ompok.etnik. (10 Desember 2017).

Hariadi, Sunarru Syamsi. 2016. Memahami Kearifan Lokal Petani Tradisional "Samin" dan Petani Modern (p. 36). Yogyakarta: Pintal.

Langerodi, M.C. 2013. Famers' Empowerment Indicators Modeling In Mazandaran Province, Iran. Internasional Journal Agricultural And Crop Sciences, 5(7). 769776.

Retnaningtyas, Agustina 2010. Kajian Nilai-Nilai Tradisional Petani Komunitas Adat Blangkon Kaitannya Dengan Usaha Tani Sawah (Studi Kasus Di Desa Pekuncen Kecamatan Jatilawang Kabupaten Banyumas). Tesis Program Pascasarjana. Universitas Sebelas Maret. Surakarta.

Widodo, Slamet. 2009. Proses Transformasi Pertanian Dan Perubahan Sosial Pada Masyarakat Samin Di Bojonegoro. Embryo, 6(1), 57-66.

Yuliati, Yayuk dan Mangku Purnomo 2003. Sosiologi Pedesaan. Jakarta: Laperta. 